\title{
CRISPR/Cas9 mediated T7 RNA polymerase gene knock-in in E. coli BW25113 makes T7 expression system work efficiently
}

\author{
Changchuan Ye ${ }^{1,2}, X_{i} C^{3}{ }^{3}$, Mengjie Yang ${ }^{4}$, Xiangfang Zeng ${ }^{1,2}$ and Shiyan Qiao ${ }^{1,2^{*}}$
}

\begin{abstract}
T7 Expression System is a common method of ensuring tight control and high-level induced expression. However, this system can only work in some bacterial strains in which the T7 RNA Polymerase gene resides in the chromosome. In this study, we successfully introduced a chromosomal copy of the T7 RNA Polymerase gene under control of the lacUV5 promoter into Escherichia coli BW25113. The T7 Expression System worked efficiently in this mutant strain named BW25113-T7. We demonstrated that this mutant strain could satisfactorily produce 5-Aminolevulinic Acid via C5 pathway. A final study was designed to enhance the controllability of T7 Expression System in this mutant strain by constructing a T7 Promoter Variants Library. These efforts advanced E. coli BW25113-T7 to be a practical host for future metabolic engineering efforts.
\end{abstract}

Keywords: E. coli, CRISPR/cas9, T7 Expression System, Fluorescent Protein, 5-Aminolevulinic Acid, promoter variants

\section{Introduction}

Metabolic engineering plays a critical part in bio-based production of fuels, chemicals and materials from biomass, and often involves integration of multiple genes to re-direct metabolic fluxes [1]. In recent years, biosynthesis techniques have attracted increased attention. As synthetic biology applications have grown in complexity, so too has the sophistication of available genetic and biochemical tools. For example, researchers started to produce antibiotic using microbial fermentation in the mid-20th century [2]. Currently, a dramatic change in the scope and complexity manufacturing processes within the space of synthetic biology has occurred. Thanks to development of genetic engineering, accomplishments have progressed from simple reconstitution of biosynthetic pathways in heterologous hosts to

\footnotetext{
* Correspondence: 87062@cau.edu.cn

${ }^{1}$ State Key Laboratory of Animal Nutrition, Ministry of Agriculture Feed Industry Centre, China Agricultural University, 100193 Beijing, China ${ }^{2}$ Beijing Key Laboratory of Bio-feed Additives, 100193 Beijing, China Full list of author information is available at the end of the article
}

ambitious refactoring efforts [3-5] that can produce high titers of medicinally relevant compounds (strictosamide, taxa-diene, etc. ) $[6,7]$ or amino acids (L-valine, L-threonine, etc. ) [8, 9]. Up to now, synthetic biologists have employed many tools to modify and reform bacterial strains to produce desired compounds. These tools include well-characterized sets of expression vectors [10], promoters for dynamic pathway control [11, 12], tunable protein degradation [13], and advanced methods for genome editing [14, 15].

Synthetic biologists prefer two organisms for expression and optimization of heterologous biosynthetic pathways: Escherichia coli and Saccharomyces cerevisiae. E. coli is the most widely used prokaryotic system that produces heterologous proteins for industrial production of bacterial metabolites by batch and fed-batch operations [16, 17]. E. coli is a gram-negative, facultative anaerobic and non-sporulating bacterium [18]. E. coli has been regarded as the workhorse of modern biotechnology in the microbial production of biofuels and biochemicals [19]. 
To express heterologous proteins in $E$. coli, researchers have designed and developed a large number of expression vectors based on specific signals (such as promoters) that bacteria can recognize. One of the most frequently used expression systems is the T7 expression system. T7 is a kind of bacteriophage with highly efficient self-replication after infection of $E$. coli. Early transcription is initiated by T7 RNA polymerase which can strongly initiate transcription of other genes [20]. The T7 expression system has several advantages such as: T7 RNA polymerase can recognize the T7 promoter specifically and initiate transcription of downstream genes; the mRNA transcribed by the T7 expression system is stable and has a strong translational signal [20,21].

To ensure the T7 expression system works in E. coli, researchers have integrated genes that code T7 RNA polymerase into the genome of some $E$. coli strains such as BL21(DE3) $[20,21]$. However, there are still some $E$. coli strains which have special characteristics, but lack the $T 7$ RNA polymerase gene. Consequently, it is of great significance to find a convenient tool to integrate a large gene (such as T7 RNA polymerase gene, more than $4 \mathrm{~kb}$ ) into the bacterial genome. A possible solution is the CRISPR/ Cas9 system which has been developed for programmable and customizable genome engineering [22].

CRISPR/Cas is an RNA-guided system which enables site-specific induction of a double strand break (DSB) and programmable genome editing. CRISPR/Cas is an immune system in bacteria and archaea [23]. Because of modularization and easy handling, CRISPR/Cas9 was adopted to engineer genomes of $E$. coli, lactic acid bacteria, streptomyces, Clostridium and so on [24]. Among CRISPR/Cas9 methods, recombineering based on $\lambda$-Red has been widely employed for genome manipulation [1], which necessitates an editing template donor DNA and three phage $\lambda$ proteins: Exo, Bet and Gam [25]. Gam prevents the host RecBCD nuclease (a kind of exonucleases in bacteria) from degrading the linear donor DNA, while Exo exonuclease resects the double-stranded DNA (dsDNA) and Bet binds the single-stranded DNA (ssDNA) to promote annealing of ssDNA to homologous chromosomal sequences [26]. Although there are many reports of successful insertion, deletion and replacement of prokaryotic genes using the CRISPR/Cas9 system, integration of large pieces of DNA into an E. coli chromosome is still facing many challenges, such as high offtarget rates, difficulty in acquiring Donor DNA and finding a suitable insertion site [27]. In this study, we manage to integrate the T7 RNA polymerase gene into the chromosome of BW25113, which is a derivative of $E$. coli K-12 W1485. Escherichia coli BW25113 is a common laboratory strain that became the parent strain for the Keio collection, a major resource consisting of approximately 4,000 single-gene deletion mutants $[28,29]$. The strain and its derivatives are being used in countless laboratories for a variety of studies, including systematic phenotypic surveys [30] and synthetic biology efforts [31-33]. Subsequently, we test the efficiency of the T7 Expression System in this mutant strain to ensure that heterogeneous expression of protein occurs.

To make our findings more useful in metabolic engineering, we designed a library of T7-Lac promoter variants. Earlier studies indicated that the T7 promoter is composed of two functional domains: an upstream binding region from -17 to -5 and an initiation region from -4 to +6 . The promoter variants library was based on T7-Lac promoter [34], and the mutants were concentrated on the binding region (Fig. 1). We tested the expression strength of these promoter variants library in BW25113-T7, which will be useful in characterizing a number of aspects of promoter functions in metabolic engineering.

\section{Results}

Selection of integration site and design of Left and Right Arm

T7 RNA polymerase gene, LacI gene, LacI Operator and Int 1 (T7-RNAP) were cloned from E. coli BL21(DE3). By referring to successful introduction in BL21(DE3), we decided to insert T7-RNAP into the $y b h C$ gene site of BW25113. Besides, we verified that the $y b h C$ gene only encodes an outer membrane lipoprotein, which would not negatively affect cell growth and metabolism after knocking out. The map of T7-RNAP in BL21(DE3) and the integration site in BW25113 are shown in Fig. 2 A and $2 \mathrm{~B}$. The left homologous arm (HRL) was set to be the downstream of the $y b h C$ gene $(854-1255 \mathrm{bp})$, and the right homologous arm (HRR) was set in the middle of the $y b h C$ gene (318-735 bp). Both homologous arms were approximately $400 \mathrm{bp}$, which could have a high efficiency of recombination [35]. The map of T7-RNAP integration in BW25113 in ideal condition is shown in Fig. 2 C. All plasmids used in this research will be listed in Table 1.

\section{Construction of plasmids for CRISPR and preparation of linear Donor DNA}

Plasmid pCas prepared by our lab harbored the temperature sensitive oriR101 with repA101ts for curing at $37^{\circ} \mathrm{C}$, kanamycin resistance gene $\left(\operatorname{Kan}^{\mathrm{r}}\right)$, and the $\lambda$ Red operon encoding Gam, Bet, and Exo proteins under the control of arabinose-inducible promoter $P_{a r a B}$. This plasmid harbored $S$. pyogenes-derived cas 9 driven by endogenous promoters and small-guide RNA (sgRNA) guided to ori-p15a which is under the control of lac operator (Figure S1A).

Plasmid pTarget-ybhC was derived by targeting the pCRISPR crRNA region to the E. coli BW25113 ybhC 


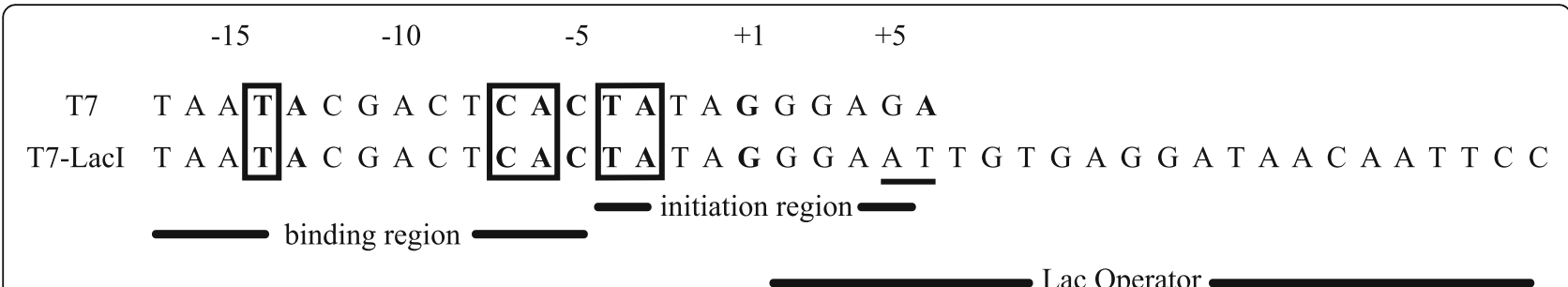

Fig. 1 Comparison of phage original T7 and T7-Lacl promoter sequences. The sequence of the non-template strand is shown about T7 and T7Lac promoters. Positions inside the squares are conserved in all 47 natural phage promoter sequences. Positions in boldface type are common among all consensus promoters. Positions that are underlined are variant parts between original T7 and T7-Lac. The binding region (-17 to -5$)$ and initiation region $(-4$ to +6$)$ of the $T 7$ promoter are indicated

gene, which harbored Chloramphenicol resistance $\left(\mathrm{Chl}^{\mathrm{r}}\right)$ and ori-p15a (Figure S1B).

Difficulty was acquiring the linear Donor DNA. The Donor DNA should contain the T7 RNA Polymerase gene and two homologous arms (HRL and HRR). The preparation of Donor DNA with high-fidelity was difficult as the T7 RNA Polymerase gene contains about $4.5 \mathrm{~kb}$. In this research, we designed two intermediate cloning vectors for preparation of Donor DNA. We expected this approach would enhance efficiency of CRIS PR/Cas9-mediated homologous recombination.

Primers used for preparation of Donor DNA are shown in Table 2. First, Fragment A (contained the $y b h C$ gene, HRR, and HRL) was cloned from the E. coli BW25113 genome by Primer ybhC-F and ybhC-R. Then
Fragment A was concatenated to pACYCD-Blank (p15a ori, $\mathrm{Chl}^{\mathrm{r}}$ ) to assemble a new plasmid: pACYCD-ybhC (Figure S2A and S2B). Next, T7-RNAP (Fragment B) was cloned from the E. coli BL21(DE3) genome by Primer RNAP-F and RNAP-R and then Fragment B was assembled with pACYCD-ybhC. Subsequently, linear Donor DNA could be cloned from this new plasmid named pACYCD-Donor (Figure S2C and S2D). Donor DNA was purified, sequenced and confirmed to be without any mutations or absences.

\section{Confirmation of CRISPR/Cas9-Mediated Gene Knock-in in BW25113}

E. coli lacks the Non-Homologous End Joining (NHEJ) mechanism to survive DNA cleavage [36] so the most

A.

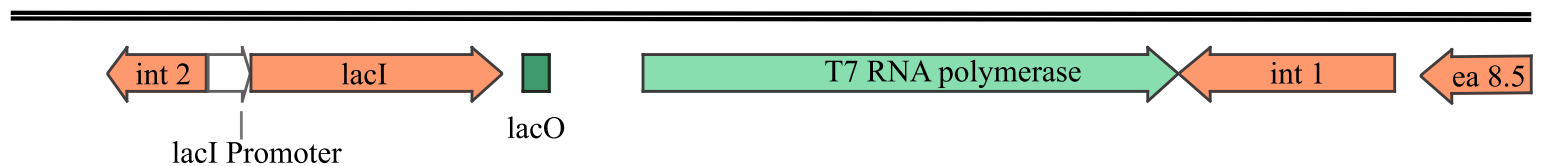

T7 RNAP

B.

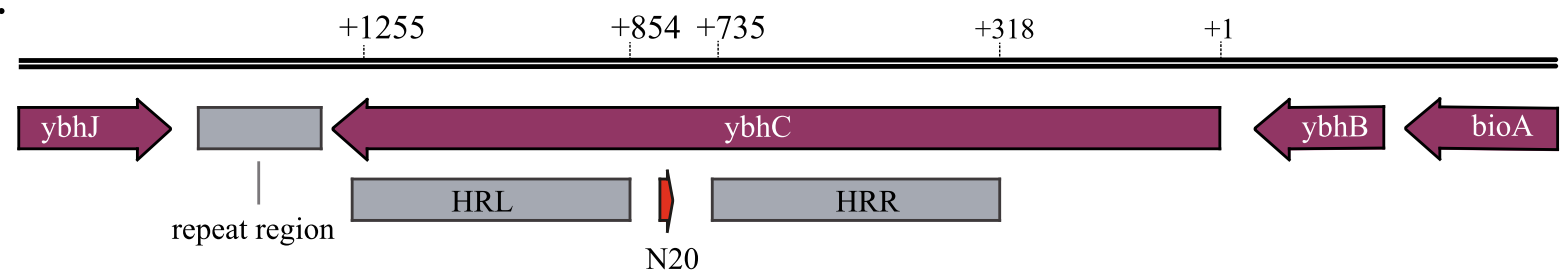

C. primer Seq-F

primer Seq-R

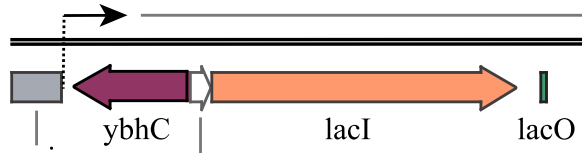

repeat region LacI Promoter

\begin{tabular}{|l|l|l|}
\hline HRL & T7 RNAP & HRR \\
\hline
\end{tabular}

Fig. 2 Gene map for targeted Cas9-mediated gene Knock-In. (A) Map of T7-RNAP in BL21(DE3), including Lacl, LacO and T7 RNA Polymerase gene. (B) Integration site in BW25113. (C) map of T7-RNAP integration in ideal condition and the location of PCR product (5496 bp) for sequencing 
Table 1 Strains and plasimds employed in this study

\begin{tabular}{|c|c|c|}
\hline Strain or plasmid & Relevant characteristic(s) & $\begin{array}{l}\text { Source and/or } \\
\text { reference }\end{array}$ \\
\hline \multicolumn{3}{|l|}{ Strain } \\
\hline Escherichia coli DH5a & $\begin{array}{l}F-, \varphi 80 d l a c Z \Delta M 15, \Delta(l a c Z Y A-\operatorname{argF}) \cup 169 \text {, deoR, recA1, endA1, hsdR17 (rK-, mK+), phoA, } \\
\text { supE44, } \lambda \text {-, thi-1, gyrA96, relA1 }\end{array}$ & TransGen, Beijing \\
\hline Escherichia coli BL21(DE3) & $\begin{array}{l}\text { fhuA2 [lon] ompT gal ( } \lambda \text { DE3) [dcm] } \Delta h s d S \lambda \text { DE3 }=\lambda \text { sBamHIo } \Delta E \text { EcoRl-B int::(lacl::PlacUV5::T7 gene) } \\
\text { i21 } \Delta \text { nin5 }\end{array}$ & TransGen, Beijing \\
\hline Escherichia coli BW25113 & F-, DE(araD-araB)567, lacZ4787(del)::rrnB-3, LAM-, rph-1, DE(rhaD-rhaB)568, hsdR514 & Laboratory stock \\
\hline Escherichia coli BW25113-T7 & BW25113 int::(lacl:::PlacUV5:::T7 gene) $\Delta y b h C$ & This study \\
\hline \multicolumn{3}{|l|}{ Plasmids } \\
\hline pACYCD-Blank & E. coli cloning vector (p15a ori; CmR) & Laboratory stock \\
\hline pACYCD-sYFP & pACYCD-Blank with sYFP gene, LaCl gene and T7-Lacl promoter & Laboratory stock \\
\hline pCas & $\begin{array}{l}\text { plasmid for CRISPR (temperature sensitive oriR101; KanR; the } \lambda \text {-Red operon under the } \\
\text { control of arabinose-inducible promoter; S. pyogenes-derived cas9; sgRNA guided to } \\
\text { ori-p15a under the control of lac operator) }\end{array}$ & Laboratory stock \\
\hline pTarget & plasmid for CRISPR (p15a ori; CmR; sgRNA) & Laboratory stock \\
\hline pTarget-ybhc & plasmid for CRISPR (p15a ori; CmR; sgRNA guided to ybhC gene) & This study \\
\hline pACYCD-ybhC & pACYCD-Blank with ybhC gene (Fragment A) & This study \\
\hline PACYCD-Donor DNA & pACYCD-Blank with Donor DNA & This study \\
\hline pACYCD-sYFP-17A (and so on) & pACYCD-sYFP with T7 Promoter Mutation Library (Single-base substitution mutation) & This study \\
\hline pET28b-ALA-LA & plasmid for biosyntheizing ALA (f1 ori; KanR; hemA; hemL; Lacl gene and T7-Lacl promoter) & Laboratory stock \\
\hline pET28b-ALA-LAR & plasmid for biosyntheizing ALA (f1 ori; KanR; hemA; hemL; RhtA; Lacl gene and T7-Lacl promoter) & Laboratory stock \\
\hline
\end{tabular}

Table 2 Primer pairs for CRISPR/Cas9 induced Knock-In

\begin{tabular}{|c|c|c|c|}
\hline Primer & Sequences (5'to3') & $\begin{array}{l}\text { Base } \\
\text { Number }\end{array}$ & Note \\
\hline Primer F1 & gcttgttggtacgcttctgccattcatccgcttattatcac & 41 & \multirow{4}{*}{$\begin{array}{l}\text { Positions in boldface type are homologous fragments designed for Takara } \\
\text { In-Fusion }\end{array}$} \\
\hline Primer R1 & accgcggcgtgggtacctggcgttacccaacttaat & 36 & \\
\hline $\begin{array}{l}\text { Primer ybhC- } \\
\text { F }\end{array}$ & tacccacgccgcggttattg & 20 & \\
\hline $\begin{array}{l}\text { Primer ybhC- } \\
\text { R }\end{array}$ & aagcgtaccaacaagcgcca & 20 & \\
\hline Primer F2 & cttttcgtgcgcgcataacgttgttaatctgtacctggtc & 40 & \multirow{6}{*}{$\begin{array}{l}\text { Positions in boldface type are homologous fragments designed for Takara } \\
\text { In-Fusion }\end{array}$} \\
\hline Primer R2 & tggtgtccgggatctgtatcgtttctggtcgcggcg & 36 & \\
\hline $\begin{array}{l}\text { Primer RNAP- } \\
\text { F }\end{array}$ & cagatcccggacaccatcga & 20 & \\
\hline $\begin{array}{l}\text { Primer RNAP- } \\
\text { R }\end{array}$ & atgcgcgcacgaaaagcatc & 20 & \\
\hline $\begin{array}{l}\text { Primer } \\
\text { Donor-F }\end{array}$ & tacccacgccgcggttattg & 20 & \\
\hline $\begin{array}{l}\text { Primer } \\
\text { Donor-R }\end{array}$ & aagcgtaccaacaagcgcca & 20 & \\
\hline Primer N20-F & gttttagagctagaaatagcaagttaaaat & 30 & \multirow[t]{2}{*}{ Embellished by 5'-phosphorylation } \\
\hline Primer N20-R & tctggaaacgaatcgtcagcactagtattatacctaggac & 40 & \\
\hline
\end{tabular}


transformants harboring pCas and pTarget would die due to co-expression of Cas9, tracrRNA and crRNA, and subsequent DSB at the protospacer. Upon DNA damage, bacteria initiate a coordinated SOS response that involves activation of RecA protein and expression of error prone polymerase $\mathrm{V}$ encoded by $u m u D C$ to facilitate mutagenic DNA repair and cell survival [37]. Together with the editing template Donor DNA and $\lambda$-Red proteins, the SOS response can repair the DSB and the donor DNA could be mediated into the chromosome by homologous recombination $[24,25,38]$.

To make CRISPR/Cas9-mediated homologous recombination in BW25113, we electroporated pCas (encoding both Cas and $\lambda$-Red proteins) into E. coli BW25113, followed by Arabinose (Ara) induction of pCas-encoded $\lambda$-Red proteins Gam, Bet and Exo. After preparing competent cells, pTarget-ybhC and Donor DNA were co-electroporated into cells (Fig. 3). The plate of cells after co-electroporating is shown in Figure S3.

To attest the integration into target locus, six bacterial colonies were selected for colony PCR (Figure S4). Primers for the test were Primer RNAP-R and Test-F (Table 2 and Table S1).

Subsequently, a rigorous examination was conducted to estimate whether T7-RNAP was integrated into the genome. The whole T7-RNAP fragment and adjacent chromosomal region (5496 bp; Fig. 2 C) were cloned from this mutant strain by Primer Seq-F and Seq- $R$ (Table S1). The PCR products were purified and sequenced to confirm that there were no mutations or absence in T7-RNAP. This mutant strain was named $E$. coli BW25113-T7.

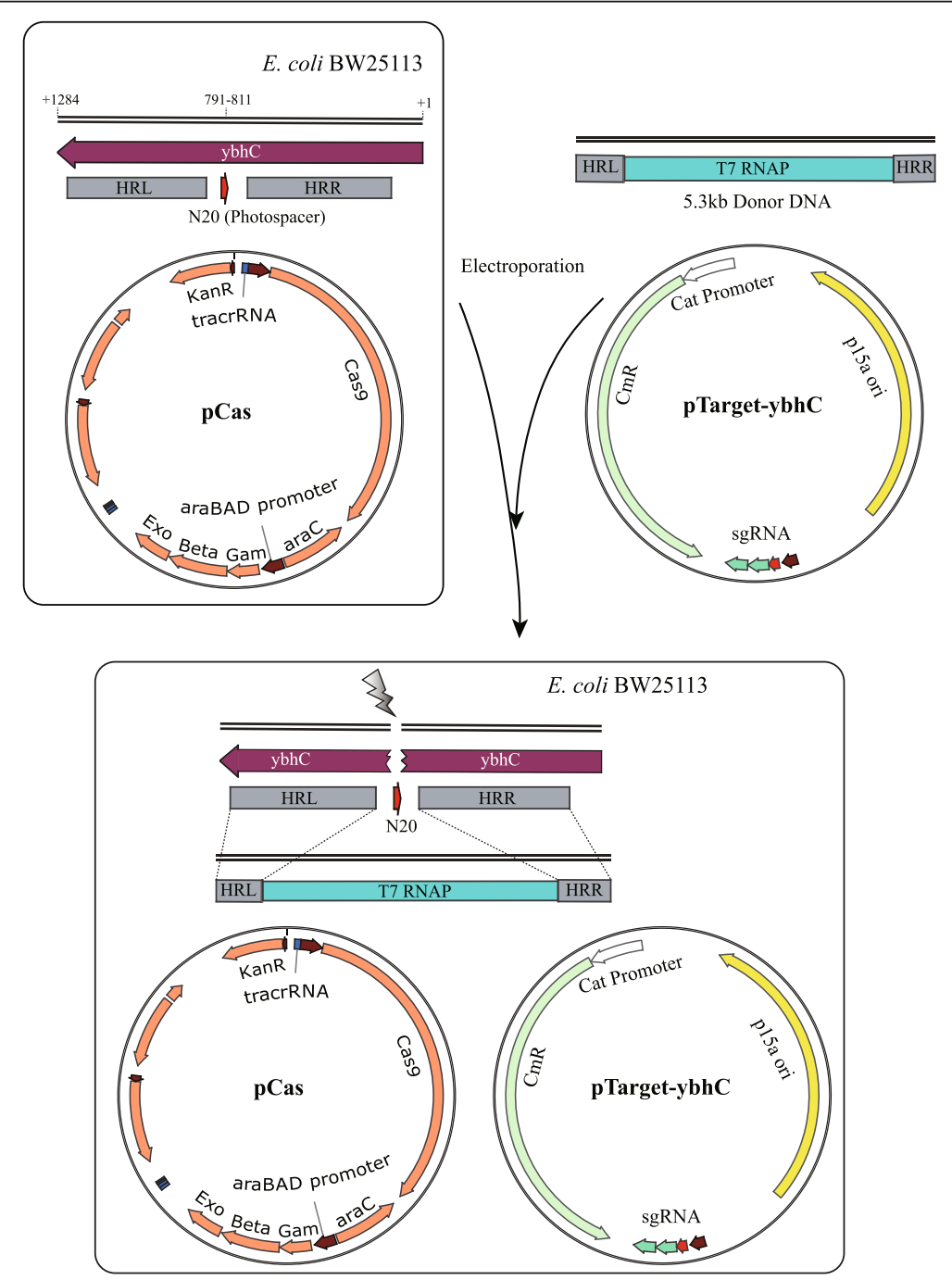

Fig. 3 Schematic illustration of DSB induction and homologous recombination. After preparing competent cells, the pTarget-ybhC and Donor DNA which harbored T7-RNAP and homology arms (HRR and HRL) that targeted a chromosomal locus spanning the middle of ybhC gene and the DSB site were electroporated into cells 


\section{Growth characteristic of E. coli BW25113-T7}

Growth of E. coli BW25113-T7 in different medium was examined to assess whether CRISPR/Cas9-mediated T7RNAP Knock-In affected the metabolic characteristics of the bacteria,

Growth of E. coli BW25113-T7 was compared with $E$. coli BW25113 and BL21(DE3). These three strains were cultured in standard M9 medium, special M9YE medium (standard M9 medium with additional $2 \mathrm{~g} / \mathrm{L}$ Yeast Extract and $10 \mathrm{~g} / \mathrm{L}$ Glucose) or standard LB medium (Fig. 4). There were no differences in growth rate among three strains in standard M9 medium (Fig. 4 A). However, growth rate of E. coli BW25113 and BW25113-T7 were higher than strain BL21(DE3) in nutrient medium such as standard LB medium or special M9YE medium (Fig. 4B C). Meanwhile, growth rate was similar between E. coli BW25113 and BW25113-T7 in these three types of medium (Fig. 4). These results indicated that induction of a chromosomal copy of the $T 7$ RNA Polymerase gene does not impact growth characteristics of E. coli BW25113-T7.

\section{Efficiency of T7 expression system in BW25113-T7}

To explore whether the T7 expression system works in BW25113-T7, we detected fluorescence from the yellow fluorescent protein, sYFP, that is controlled by T7-Lac promoter (Figure S5) in BW25113-T7 with IPTG induction (Fig. 5). The T7-Lac promoter did not activate expression of sYFP in E. coli BW25113 because it lacked T7 RNA Polymerase gene (Fig. 5 A). After T7-RNAP knock-in, sYFP was expressed under control of T7-Lac promoter in E. coli BW25113-T7. Subsequently, the fluorescent signal could be macroscopically observed by Confocal Microscopy (Fig. 5B C). This result indicated that this mutant strain did express heterologous proteins efficiently through the T7 Expression System.

The quantitative fluorescent signal was detected by a Multifunctional Microplate Detector (Table 3). The fluorescent signal in E. coli BW25113-T7 was detected as 5636, which was about 4 times greater than that in $E$. coli BL21(DE3) (Fig. 6 A). It means that expression strength of sYFP under control of T7-Lac promoter in BW25113-T7 was greater than BL21(DE3) $(\mathrm{p}<0.001)$. These results revealed that the T7 expression system has an enhanced efficiency in E. coli BW25113-T7.

\section{Production of 5-Aminolevulinic Acid via C5 pathway}

To further ascertain the biosynthetic efficiency and metabolic engineering potential in E. coli BW25113-T7, we designed a process for 5-Aminolevulinic Acid biosynthesis in this mutant strain.

5-Aminolevulinic Acid (ALA), a five-carbon amino acid, is a key intermediate involved in the biosynthesis of tetrapyrrole [39]. ALA recently received much attention due to its potential applications in many fields, such as tumor-localization and photodynamic therapy for various cancers [40-42]. ALA is also used as a selective biodegradable herbicide and insecticide in agricultural applications due to its nontoxicity to crops, animals, and humans $[43,44]$. Currently, biosynthesis of ALA has become the focus of much research [45]. In living organisms, there are two major pathways described for ALA biosynthesis: C4 pathway and C5 pathway [43]. The C5 pathway occurs in higher plants, algae, and many bacteria including $E$. coli [46]. In the C5 pathway, glutamate is the only substrate for biosynthesis of ALA. In E. coli, a metabolic strategy of ALA biosynthesis via C5 pathway has been developed [39]. Through this strategy, ALA can be synthesized in E. coli by over-expressing the key

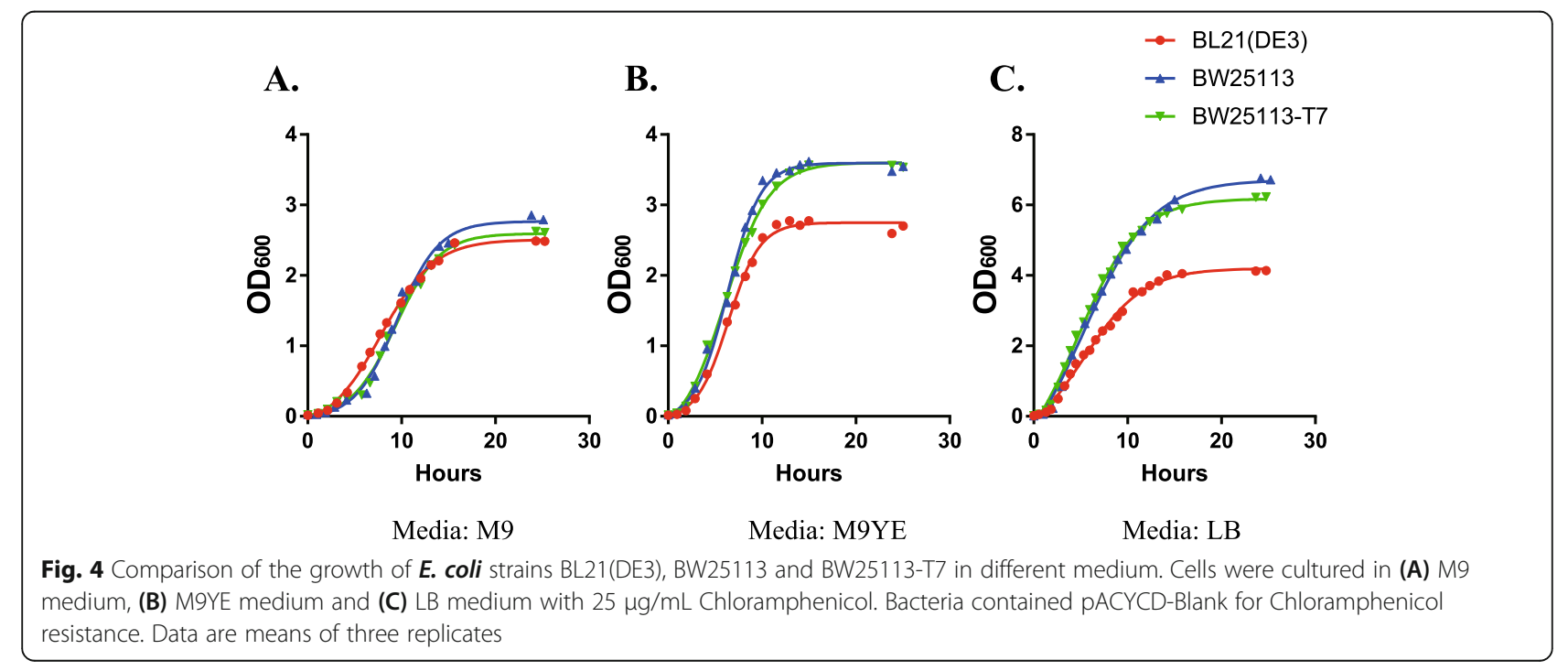




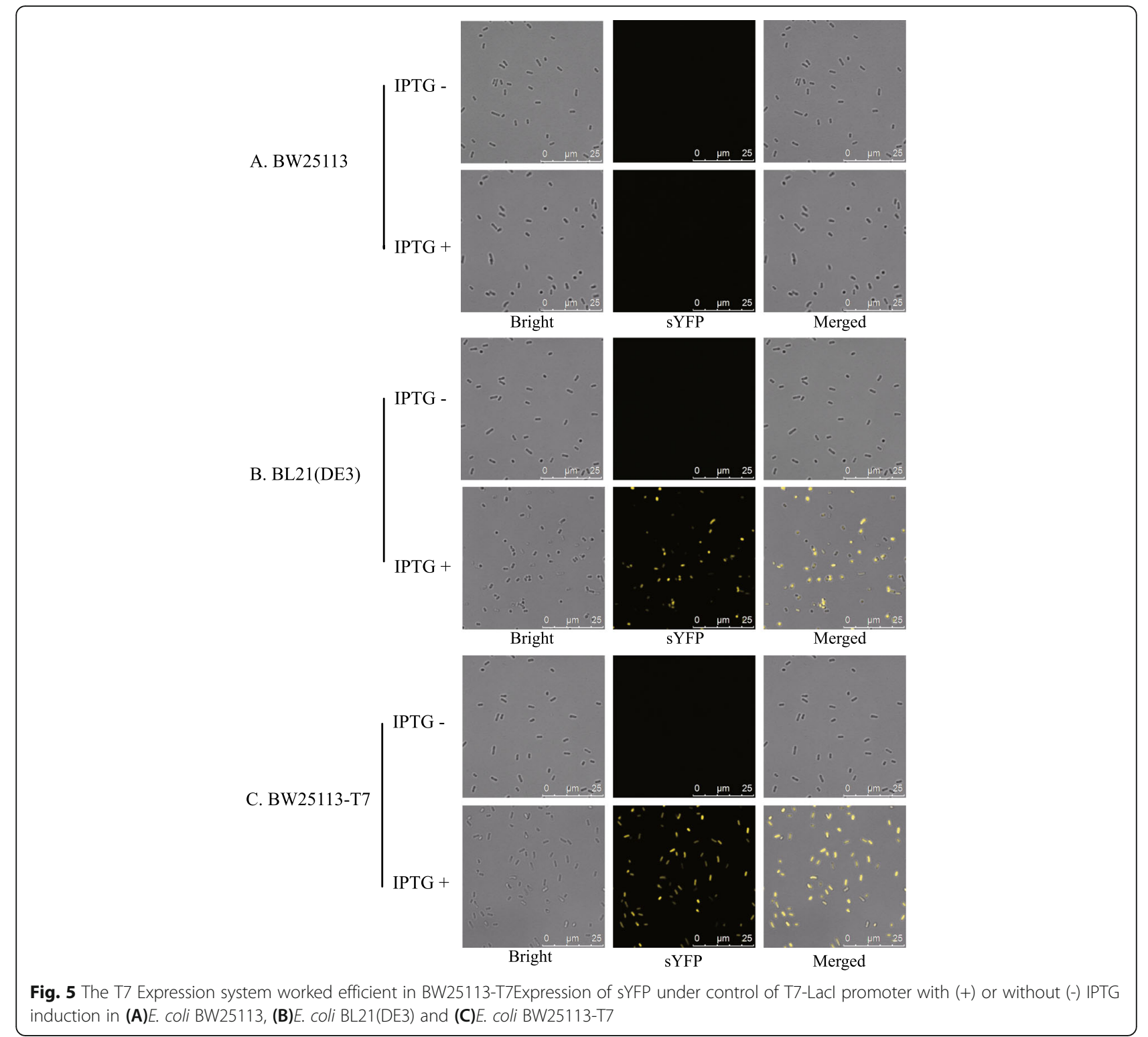

genes, hemA and hemL. In this research, we used a similar process for ALA biosynthesis (Fig. 7). In our mutant strain, the key genes, hemA and hemL, were expressed efficiently and controlled by T7 Expression System.

Synthesis efficiency of ALA was compared among three strains of $E$. coli. After transferring pET28b-ALALA or pET28b-ALA-LAR (Fig. 7), cells were cultured in special M9YE medium. Genes, hemA and hemL, were over-expressed under control of T7-Lac promoter in expression vector pET28b-ALA-LA, while an ALA exporter gene $R h t A$ was over-expressed additionally in expression vector pET28b-ALA-LAR. RhtA is classified as amino acid secondary transporters and capable of translocating a variety of amino acids and related compounds, such as dipeptide and amino acid analogs. As ALA has similar chemical structure to glycylglycine and its physical properties are close to native amino acids carrying uncharged side chains, amino acid exporters with wide substrate specificity such as $R h t A$ was supposed to play roles in ALA export. RhtA encodes an inner membrane transporter, which is responsible for threonine and homoserine efflux transport.

After $24 \mathrm{~h}$ of fermentation, ALA concentration was determined (Table 4; Fig. 6B). Concentration of ALA in the fermentation broth of BW25113-T7 was $165.8 \mathrm{mg} / \mathrm{L}$, which was similar to that of BL21(DE3) when hemL and hemA were over-expressed. However, both of these two bacterial strains had a higher production of ALA when $R h t A$ was also over-expressed. After 24 h cultivation, a titer of ALA (891.9 mg/L) was achieved in BW25113-T7, which was significantly higher than that of BL21(DE3) (626.3 mg/L). Notably, efficiency of ALA metabolism 
Table 3 Expression of sYFP under control of T7-Lacl promoter in different bacterial strains

\begin{tabular}{llll}
\hline Strains & Plasmid & Expressed genes & Fluorescent signal \\
\hline BW25113 & pACYCD-SYFP & SYFP & $63 \pm 89$ \\
BW25113-T7 & PACYCD-SYFP & SYFP & $1402 \pm 221$ \\
BL21(DE3) & PACYCD-SYFP & SYFP & $5635 \pm 43$
\end{tabular}

The results are the average of three individual experiments

synthesis in BW25113-T7 was significantly higher $(\mathrm{p}<$ 0.001 ) than that of BL21(DE3) when these three key genes (hemA, hemL and $R h t A)$ were over-expressed simultaneously by the T7 Expression System.

\section{Construction of the T7 Promoter Variants Library}

The T7 Expression system was driven by T7 promoter which is recognized by $T 7 R N A$ polymerase. Relatively small amounts of bacteriophage T7 RNA polymerase can direct most of the resources of an E. coli cell toward expression of a specific target gene [20]. However, such active transcription can be a problem in expression systems where T7 RNA polymerase is supplied to the cell by induction. In this research, we constructed a library of T7-Lac promoter variants to make the T7 Expression System in E. coli BW25113-T7 more controllable.

This Promoter Variants Library was based on T7-Lac promoter, and the mutation sites were concentrated on the binding region (Fig. 1). Desired mutations were introduced into the test promoter $(\mathrm{Px})$ in pACYCD-sYFP by Inverse-PCR and mismatched primers as described in Table S2. To improve the efficiency of rephrase-self connection recombination, the reverse primer was embellished by 5 '-phosphorylation.

The resulting plasmid contains the test promoter recognized by T7 RNAP and sYFP which is driven by this promoter (Figure S5). Utilization of each of these promoters may be determined by comparing production of a runoff product (Fluorescent signal) of characteristic size from each promoter (Fig. 8). The results are summarized in Table 5. For convenience, we identify promoter variants by referring to the base in the nontemplate strand of the DNA (e.g., a -17 A promoter).

The Promoter Variants Library constructed in this study was not for the mechanism of the intensity change caused by single base mutation, but to apply this Library in biosynthetic engineering. By construction of this Library, promoter variants with different strengths were obtained. Therefore, expression of targeted gene can be regulated conveniently by replacing T7-Lac promoter variants with the required strength (Table 5). For convenient applying in synthetic biology, the re-ordered Promoter Variants Library (from the strongest promoter to the weakest promoter) was listed in the supplemental material (Figure S6 and Table S3). Construction of the
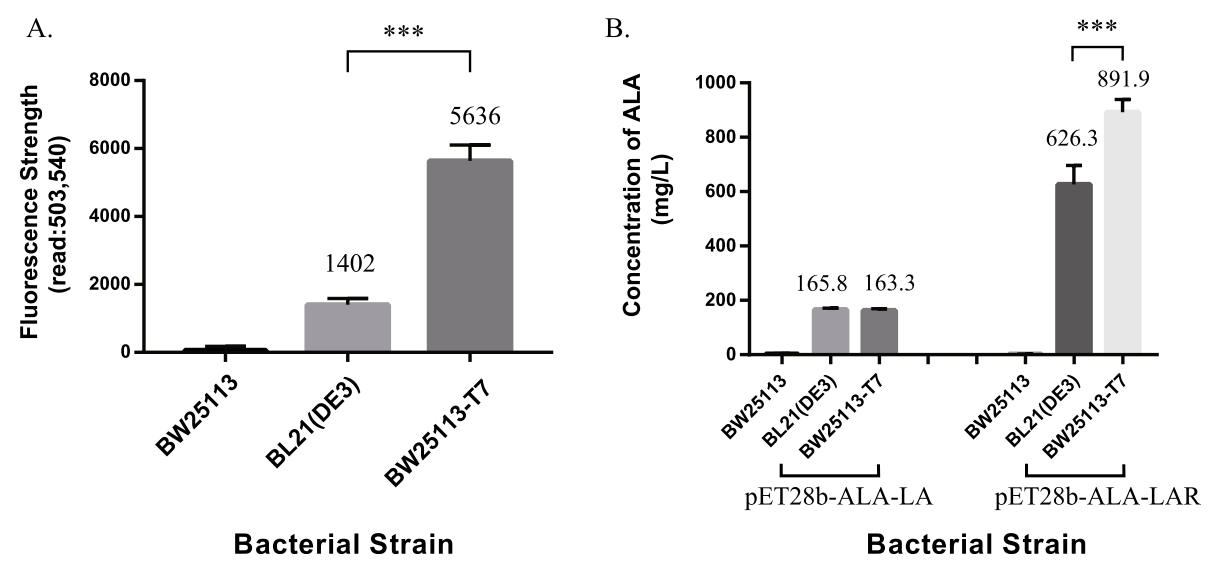

Fig. 6 Confirmation of the efficiency of the T7 expression system in BW25113-T7. (A) Expression of sYFP under control of T7-Lacl promoter in different bacterial strains. The fluorescent signal was detected by Multimode Reader (read: 503, 540) and was normalized to the cell density $\left(\mathrm{OD}_{600}\right)$. (B) The biosynthesis of ALA (5-Aminolevulinic Acid) by T7 Expression System in different bacterial strains. These strains were cultured in Medium M9YE. All experiments were performed in triplicates. $P$ values were calculated using Tukey's multiple comparisons test ${ }^{*} P<0.05$, ${ }^{* *} P<$ $\left.0.01,{ }^{* * *} P<0.001\right)$ 


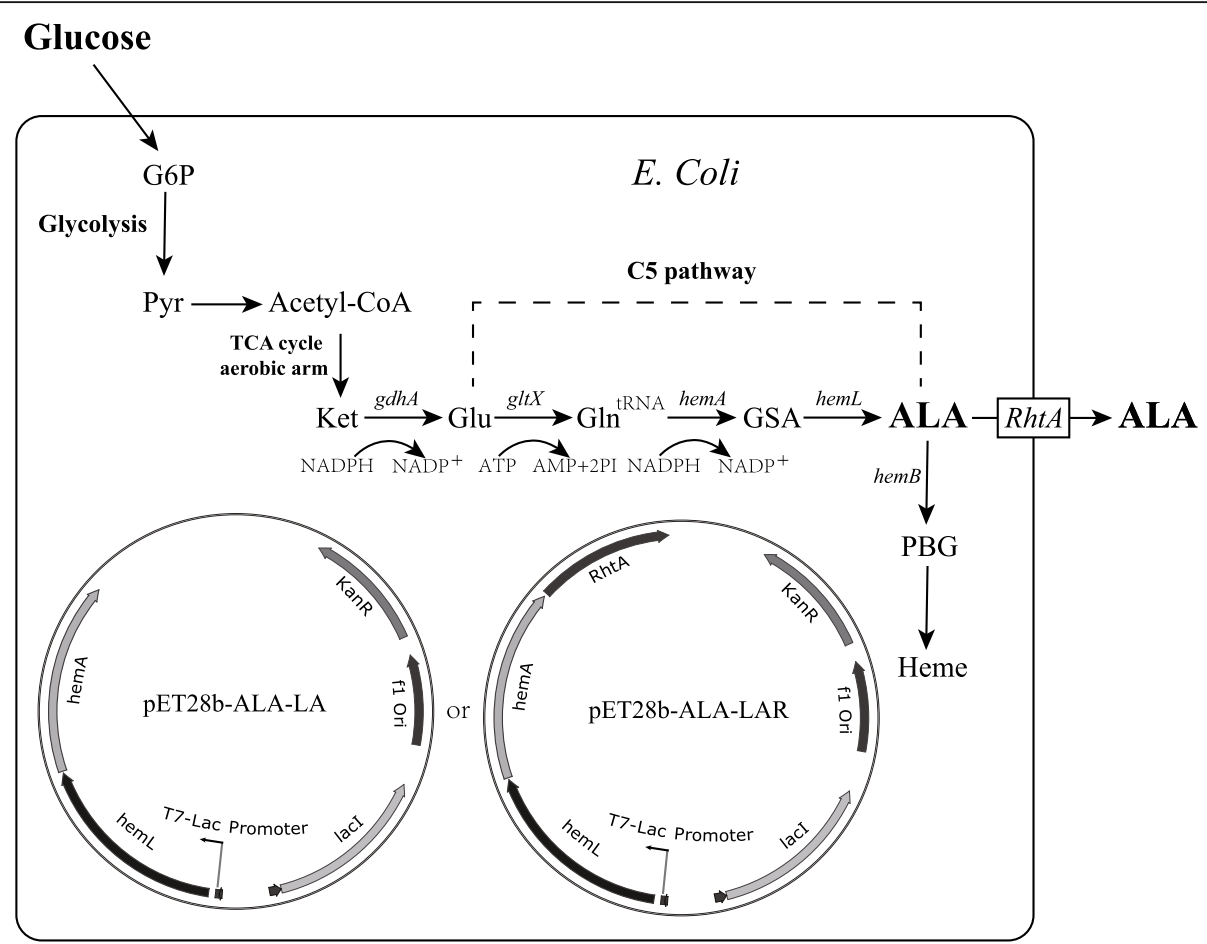

Fig. 7 Schematic presentation of ALA production from glucose in E. coli via C5 pathway. G6P, glucose-6-phosphate; Pyr, pyruvate; Ket, a-ketoglutarate; Glu, glutamate; Gln $^{\text {tRNA }}$, Glutamyl-tRNA; GSA, glutamate 1-semialdehyde aminotransferase; ALA, 5-aminolevulinic acid; PBG, porphobilinogen

Promoter Variants Library makes the T7 expression system more controllable in our newly engineered-strain: BW25113-T7.

\section{Discussion}

As a common strategy of high-level induced expression, T7 expression system can ensure tight control to make the gene to be expressed in a plasmid under the control of a T7 phage promoter. T7 RNA polymerase is highly selective for its own promoters, which do not occur naturally in E. coli. A relatively small amount of T7 RNA polymerase provided from a cloned copy of $\mathrm{T} 7$ gene is sufficient to direct high-level transcription from a T7 promoter in a multicopy plasmid [20]. Specific mRNAs produced by T7 RNA polymerase are relatively stable and can rapidly saturate the translational machinery of E. coli, so that the rate of protein synthesis from the
mRNA will depend primarily on efficiency of its translation. When mRNA is efficiently translated, a target protein can accumulate to greater than $50 \%$ of the total cell protein in three hours or less [20, 21].

To express heterologous proteins by the T7 Expression System, active T7 RNA polymerase was delivered to bacterial strains such as BL21(DE3) by induction of a chromosomal copy of T7 RNA Polymerase gene under control of the lacUV5 promoter (Fig. 2 A) [20, 21]. Expression plasmid vectors have been constructed to allow target genes to be placed under control of the T7-Lac promoter and to be expressed in bacteria strains which carry an inducible gene for T7 RNA Polymerase [34]. Transcription can be repressed strongly by lac repressor bound to an operator centered 15 base-pairs downstream from the RNA start. But, T7 RNA polymerase initiates transcription very actively from this T7-Lac

Table 4 ALA production in different bacterial strains expressing various related genes

\begin{tabular}{llll}
\hline Strains & Plasmid & Expressed genes & ALA accumulation (mg/L) \\
\hline BW25113 & pET28b-ALA-LA & hemA, hemL & $2.9 \pm 0.9$ \\
BW25113-T7 & pET28b-ALA-LA & hemA, hemL & $165.8 \pm 2.7$ \\
BL21(DE3) & pET28b-ALA-LA & hemA, hemL \\
BW25113 & pET28b-ALA-LAR & hemA, hemL, RhtA \\
BW25113-T7 & pET28b-ALA-LAR & hemA, hemL, RhtA \\
BL21(DE3) & pET28b-ALA-LAR & hemA, hemL, RhtA & $2.4 \pm 0.3$ \\
\hline
\end{tabular}

The results are the average of three individual experiments 


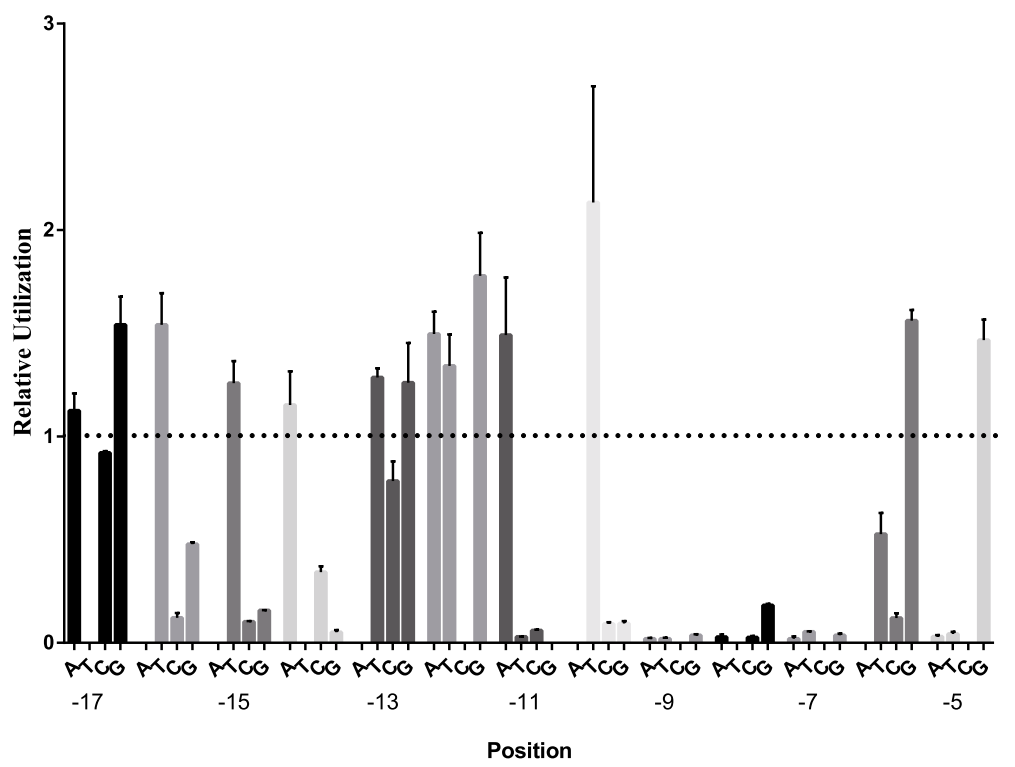

Fig. 8 Characterization of T7 RNAP promoter variants: Relative activity of promoter variants. Promoter variants were identified by referring to the base in the non-template strand of the DNA (e.g., a -17 A promoter). The height of each bar indicates the activity of each promoter relative to that of the consensus promoter (data are from Table 5). All experiments were performed in triplicates

promoter-operator combination in the absence of a repressor, or in the presence of a repressor plus inducer. To achieve a low basal expression of target genes, expression plasmid vectors usually carry a LacI gene that provides enough lac repressor to repress both the T7Lac promoter in the multicopy vectors and the chromosomal gene for T7 RNA polymerase, which is controlled by the lacUV5 promoter. Upon induction, the usual high levels of expression are obtained [34, 47].

However, only strains with the T7 RNA Polymerase gene can use the T7 Expression System for efficient and controllable protein expression. Some strains commonly used in metabolic engineering (such as E. coli BW25113) cannot utilize the T7 Expression System even though they may have some superior characteristics (a higher growth rate or lower level of enterotoxin) [48, 49]. In this study, the CRISPR/Cas9 system combined with the $\lambda$-Red homologous recombination repair system was used to complete the insertion of the T7 RNA Polymerase gene into the genome of $E$. coli BW25113. We found that induction of a chromosomal copy of the T7 RNA Polymerase gene did not affect growth characteristics and enabled the T7 Expression System in this mutant strain for heterologous protein expression or gene overexpression.

The CRISPR/Cas9 system is an efficient and highly targeted gene editing tool. Since its discovery, Cas9 has been extensively used for genome editing in multiple organisms [27]. Although the full potential of CRISPR/ Cas9 has not yet been harnessed, this technology has brought forth revolutionary changes in genomic research, including genome editing, regulation, and imaging [24, 50]. Despite Cas9's great potential for both research and therapeutics, improvements can still be made in its specificity, efficiency, and spatiotemporal control [51]. There are still some challenges of CRISPR/ Cas9 mediated large DNA Knock-In, such as high offtarget rate, difficult access for Donor DNA, and high mutation rate of knock-in fragments [24, 52]. Based on the principle of ensuring fidelity of the repair template (Donor DNA), this study constructed two intermediate plasmids (pACYCD-ybhC and pACYCD-Donor) to acquire Donor DNA with high fidelity. The large DNA (T7-RNAP, $5.4 \mathrm{~kb}$ ) was inserted into the genome of $E$. coli BW25113, and this mutant strain was named BW25113-T7.

The working efficiency of the T7 expression system in E. coli BW25113-T7 was confirmed by FluorescentProtein-Based Reporter Gene System (Fig. 5). In this mutant strain, the T7 expression system expressed the sYFP fluorescent protein and the efficiency of protein expression was higher than that of BL21 (DE3) (Fig. 6 A). Therefore, E. coli BW25113-T7 might provide the ability to produce high titers of simple peptides by the T7 Expression System.

The advantage of this protein expression could also extend to metabolic engineering. We speculate that the T7 Expression System in E. coli BW25113-T7 has greater efficiency of expression efficiency than BL21(DE3). Thus, three genes overexpressed by T7 Expression System 
Table 5 Utilization of T7 promoter variants

\begin{tabular}{|c|c|c|c|c|c|}
\hline Plasmid $^{a}$ & $\mathrm{Px}^{b}$ & Consensus base $^{c}$ & Naturally occurring promoters ${ }^{d}$ & Relative promoter strength ${ }^{e}$ & Standard error \\
\hline$\overline{\text { pACYCD-sYFP }}$ & consensus & & & 1 & \\
\hline pACYCD-sYFP-17A & $-17 \mathrm{~A}$ & T & & 1.12 & 0.07 \\
\hline pACYCD-sYFP-17C & $-17 C$ & & & 0.92 & 0.01 \\
\hline pACYCD-sYFP-17G & $-17 G$ & & $\varphi 1.1 \mathrm{~A}, 4 \mathrm{C}, 4.7$ & 1.54 & 0.11 \\
\hline pACYCD-sYFP-16C & $-16 C$ & A & & 0.12 & 0.02 \\
\hline pACYCD-sYFP-16G & $-16 G$ & & & 0.48 & 0.01 \\
\hline pACYCD-sYFP-16T & $-16 \mathrm{~T}$ & & $\varphi 4.7$ & 1.54 & 0.13 \\
\hline pACYCD-sYFP-15C & $-15 C$ & A & & 0.10 & 0.00 \\
\hline pACYCD-sYFP-15G & $-15 G$ & & & 0.16 & 0.00 \\
\hline pACYCD-sYFP-15T & $-15 T$ & & & 1.26 & 0.09 \\
\hline pACYCD-sYFP-14A & $-14 \mathrm{~A}$ & T & & 1.15 & 0.13 \\
\hline pACYCD-sYFP-14C & $-14 C$ & & & 0.34 & 0.02 \\
\hline pACYCD-sYFP-14G & $-14 G$ & & & 0.05 & 0.01 \\
\hline pACYCD-sYFP-13C & $-13 C$ & $A$ & $\varphi 4 c$ & 0.78 & 0.08 \\
\hline pACYCD-sYFP-13G & $-13 G$ & & & 1.26 & 0.16 \\
\hline pACYCD-sYFP-13T & $-13 \mathrm{~T}$ & & $\varphi 3.8,4.7$ & 1.29 & 0.04 \\
\hline pACYCD-sYFP-12A & $-12 A$ & C & & 1.50 & 0.09 \\
\hline pACYCD-sYFP-12G & $-12 \mathrm{G}$ & & $\varphi 3.8$ & 1.78 & 0.17 \\
\hline pACYCD-sYFP-12T & $-12 \mathrm{~T}$ & & & 1.34 & 0.13 \\
\hline pACYCD-sYFP-11A & $-11 \mathrm{~A}$ & G & $\varphi \mathrm{OL}, 3.8$ & 1.49 & 0.23 \\
\hline pACYCD-sYFP-11C & $-11 C$ & & & 0.06 & 0.00 \\
\hline pACYCD-sYFP-11T & $-11 T$ & & & 0.03 & 0.00 \\
\hline pACYCD-sYFP-10C & $-10 C$ & A & & 0.09 & 0.01 \\
\hline pACYCD-sYFP-10G & $-10 G$ & & & 0.09 & 0.01 \\
\hline pACYCD-sYFP-10T & $-10 T$ & & & 2.13 & 0.46 \\
\hline pACYCD-sYFP-9A & $-9 A$ & C & & 0.02 & 0.00 \\
\hline pACYCD-sYFP-9G & $-9 \mathrm{G}$ & & & 0.04 & 0.00 \\
\hline pACYCD-sYFP-9T & $-9 T$ & & & 0.02 & 0.00 \\
\hline pACYCD-sYFP-8A & $-8 \mathrm{~A}$ & T & & 0.03 & 0.01 \\
\hline pACYCD-sYFP-8C & $-8 C$ & & & 0.03 & 0.01 \\
\hline pACYCD-sYFP-8G & $-8 \mathrm{G}$ & & & 0.18 & 0.01 \\
\hline pACYCD-sYFP-7A & $-7 A$ & C & & 0.02 & 0.01 \\
\hline pACYCD-sYFP-7G & $-7 G$ & & & 0.04 & 0.01 \\
\hline pACYCD-sYFP-7T & $-7 \mathrm{~T}$ & & & 0.05 & 0.00 \\
\hline pACYCD-sYFP-6C & $-6 C$ & $A$ & & 0.12 & 0.02 \\
\hline pACYCD-sYFP-6G & $-6 G$ & & & 1.56 & 0.04 \\
\hline pACYCD-sYFP-6T & $-6 \mathrm{~T}$ & & & 0.53 & 0.08 \\
\hline pACYCD-sYFP-5A & $-5 \mathrm{~A}$ & C & & 0.03 & 0.01 \\
\hline pACYCD-sYFP-5G & $-5 G$ & & & 1.47 & 0.08 \\
\hline pACYCD-sYFP-5T & $-5 T$ & & & 0.04 & 0.01 \\
\hline
\end{tabular}

aplasmids in the PACYCD series were constructed in this work

${ }^{\mathrm{b}}$ Promoter variants are designated as $\mathrm{P}-\mathrm{nX}$, where $\mathrm{n}$ indicates the position in the promoter and $\mathrm{X}$ indicates the base in the non-template strand ${ }^{c}$ The base in the non-template strand of the consensus promoter at the indicated position

${ }^{\mathrm{d} N a t u r a l l y ~ o c c u r r i n g ~ T 7 ~ R N A ~ P o l y m e r a s e ~ c l a s s ~ I I ~ p r o m o t e r s ~ t h a t ~ c o n t a i n ~ t h e ~ i n d i c a t e d ~ s u b s t i t u t i o n ; ~ a l l ~ c l a s s ~ I I ~ p r o m o t e r s ~ h a v e ~ t w o ~ o r ~ m o r e ~ s u b s t i t u t i o n s ~}$ ePlasmid templates were transcribed as described in Fig. 11, and the products (Fluorescent signal) were measured by Synergy ${ }^{\mathrm{TM}}$ HTX Multifunctional Microplate Detector The utilization of each mutant promoter was then expressed relative to that of the consensus promoter when it was present at the position of Px 
(hemA, hemL and RhtA) in BW25113-T7 were all expressed at higher levels than BL21(DE3). When key synthetase genes, hemA and hemL, were over-expressed by the T7 Expression System, there were no differences between BW25113-T7 and BL21 (DE3) in ALA production (Fig. 6B). This result is easily explained, as the accumulation of compounds is more closely related to the activity and quality than quantity of synthetase in metabolic engineering $[10,39,53]$. However, when the exporter gene, $R h t A$, was over-expressed in addition to hemA and hemL, production of ALA in BW25113-T7 was significantly higher than that of BL21(DE3) (Fig. 6B). Therefore, we speculate that rate of ALA export in the BW25113-T7 strain is higher than that of BL21 (DE3) due to greater expression of RhtA. As a result of accelerated ALA export, E. coli BW25113-T7 accumulated $42.4 \%$ more than E. coli BL21(DE3) (Fig. 6B).

Our mutant strain BW25113-T7 retains the characteristic rapid growth of the original strain. Although there were no differences of growth rate between BW25113T7 and BL21(DE3) in minimal medium, BW25113-T7 showed faster growth when cultured in nutrient medium (Fig. 4). These results demonstrated that after T7-RNAP Knock-In, this mutant strain has certain advantages in metabolic engineering and synthetic biology. Otherwise, E. coli BW25113-T7 still has potential for genetic modification. This strain can be further edited and modified according to specific metabolic engineering strategies to make it more suitable for production of required compounds.

There are some disadvantages with the T7 Expression System. Due to the abnormally high activity of T7 polymerase, this inducible expression system is not the optimal choice for many applications in metabolic engineering. When the T7 Expression System was activated upon induction, a target protein can accumulate to greater than $50 \%$ of the total cell protein [20]. The high levels of protein expression would be a burden on cells, which leads to a negative impact on bacterial growth. Besides, synthetic biologists working in metabolic engineering are concentrated on activity and quality of synthetase not just quantity of synthetase [10, 39, 53]. Therefore, application of T7 Expression System still has some limitations in metabolic engineering. As an attempt to enhance controllability and practicability of the T7 Expression System in this mutant strain BW25113T7 for metabolic engineering, we designed a series of experiments to construct a T7 Promoter Variants Library.

The essence of this T7 Promoter Variants Library is a series of promoter variants obtained by single-base mutation of each of the 13 bases on the Binding Region of the T7-Lac promoter (Fig. 1). Characterization of this series of promoters was measured by FluorescentProtein-Based Reporter Gene System (Fig. 8; Table 5).
Based on such a library of promoters, expression of targeted proteins can be adjusted in a controlled manner such that application of the T7 expression system can be extended. We can flexibly regulate expression of targeted proteins according to specific needs to obtain the best yield of metabolites. For example, when we desired a higher intensity expression of heterologous protein, the T7-Lac promoter can be replaced as a variant with a higher expression intensity.

In conclusion, the T7 RNA Polymerase gene was inserted into $E$. coli BW25113 genome by CRISPR/Cas9 to construct a new E. coli strain in this study. This mutant strain maintained the advantages the original strain (such as the rapid growth rate) and allowed for efficient and controllable protein expression using the T7 Expression System. Further study of constructing T7 Promoter Variants Library enhanced the application of this strain in synthetic biology and provided a technical basis for industrial production in the future. Accordingly, these efforts advanced E. coli BW25113-T7 to be a practical host for future metabolic engineering efforts.

\section{Materials and methods}

\section{E. coli Strains}

DH5 $\alpha$ (TransGen, Beijing) was used for cloning plasmid. BL21(DE3) (TransGen, Beijing) was used for cloning $T 7$ RNA polymerase genes, $L a c I$ and $L a c O$ (T7-RNAP), from its chromosomal genome. BW25113 strains were used for CRISPR/Cas9-induced DSB and recombination. All E. coli strains were routinely cultured in standard LB medium when not mentioned otherwise.

\section{Selection of integration site and design of homologous recombination}

Sequence of T7-RNAP in BL21(DE3) genome and the integration site of BW25113 were both confirmed in NCBI. The function and detailed message of the $y b h C$ gene was verified in NCBI and BioCyc Database. As the recognition site for sgRNA, N20 site directs the Cas9 protein to enable site-specific induction of a DSB. The N20 site was found by BROAD international design tool, which is available at: http://www.broadinstitute.org/rnai/ public/analysis-tools/sgrna-design.

\section{Plasmids Construction for CRISPR and preparation of linear Donor dsDNA by PCR}

Table 2 contains all primer pairs we designed for gene cloning and intermediate plasmid construction. Plasmid pCas (Figure S1A) and pTarget were prepared in our laboratory. Plasmid pTarget-ybhC was constructed by Inverse-PCR and T4-Ligation (T4 DNA Ligase, NEB, England) to replace the N20 fragment (Figure S1B) with specific primers (Table 2). Plasmid pACYCD-ybhC and pACYCD-Donor were both constructed for preparing 
Donor DNA (Figure S2) by In-Fusion ${ }^{\circ}$ HD Cloning Kit (Takara, Japan). Donor DNA was cloned from pACYCDDonor by Hi-Fi PCR (Phusion ${ }^{\circ}$ High-Fidelity PCR Master Mix, NEB, England).

All plasmids used in this research will be listed in Table 1.

\section{Electroporation, Cell Recovery, and Plating}

For transformation, the plasmid or linear DNA were electroporated into competent cells in the pre-chilled cuvette $(0.1 \mathrm{~cm})$ using Bio-Rad MicroPulser $(1.8 \mathrm{kV}$, time constant $>5.0 \mathrm{~ms})$. For selection, $25 \mu \mathrm{g} / \mathrm{mL}$ chloramphenicol (Chl) or $50 \mu \mathrm{g} / \mathrm{mL}$ kanamycin (Kan) were used alone or in combination. For induction of $\lambda$-Red proteins and lac operator, $1 \mathrm{mM}$ arabinose and $1 \mathrm{mM}$ IPTG were used.

To prepare cells harboring pCas, cells cultured at $37^{\circ} \mathrm{C}$ $\left(\mathrm{OD}_{600}=0.45-0.55\right)$ were made competent, mixed with pCas (100 ng) and subjected to electroporation, after which the cells were recovered in SOC medium $(1 \mathrm{~mL})$ for $1 \mathrm{~h}$ at $30^{\circ} \mathrm{C}$, plated onto the Kan plate, and cultured at $30{ }^{\circ} \mathrm{C}$ for $18-24 \mathrm{~h}$.

For CRISPR/Cas9-mediated homologous recombination, cells harboring pCas were cultured at $30^{\circ} \mathrm{C}$ in medium containing Kan and Arabinose and made competent. After co-electroporation of Donor DNA (400 ng) with pTarget-ybhC $(100 \mathrm{ng})$, cells were recovered in SOC $(1 \mathrm{~mL})$ medium for $1 \mathrm{~h}$ at $30^{\circ} \mathrm{C}$, plated onto $\mathrm{Chl} /$ Kan plate, and cultured at $30^{\circ} \mathrm{C}$ for $18-24 \mathrm{~h}$.

For elimination of pTarget-ybhC, cells harboring both pCas and pTarget were cultured at $30^{\circ} \mathrm{C}$ in medium containing Kan and IPTG for $2 \mathrm{~h}$. Cells were plated onto Kan plates and cultured at $30^{\circ} \mathrm{C}$ for $18-24 \mathrm{~h}$.

For elimination of pCas, cells harboring pCas were cultured at $37^{\circ} \mathrm{C}$ in the medium without any antibiotic for $12-16 \mathrm{~h}$. Then the cells were plated onto nonantibiotic plates and cultured at $37^{\circ} \mathrm{C}$ for $12-16 \mathrm{~h}$.

\section{Verification of Gene Integration by Colony PCR and DNA- seq}

To verify correct integration of T7-RNAP, we designed Primer Seq-F and Primer Seq- $R$ as shown in Table S1. Primer Seq-F targeted downstream of the $y b h C$ gene (1267-1288 bp), while Primer Seq- $\mathrm{R}$ targeted upstream of the $y b h C$ gene (261-282 bp). If integration was successful, colony PCR of the recombinants would yield $\mathrm{a} \approx 5 \mathrm{~kb}$ amplicon, which contains HRL, T7-RNAP and HRR. Absences or mutations of the integration fragment were verified by DNA-sequencing.

All DNA-sequencing for this research was conducted by Beijing Ruibio BioTech Co., Ltd (China, Beijing).

\section{Growth of bacteria in different medium}

All E. coli strains were grown at $37^{\circ} \mathrm{C}$ in conical flask $(250 \mathrm{~mL})$ containing M9 medium $(100 \mathrm{~mL})$, M9YE medium or LB medium with chloramphenicol $(25 \mu \mathrm{g} /$ $\mathrm{mL})$. Growth was measured by monitoring optical density at $600 \mathrm{~nm}\left(\mathrm{OD}_{600}\right)$ using a spectrophotometer.

\section{Confirmation of T7 Expression System in BW25113-T7 by sYFP Reporter Gene System}

Efficiency of the T7 expression system was confirmed by a fluorescent protein reporter assay system. The plasmid was named as pACYCD-sYFP, which harbored ori-p15a, Chloramphenicol resistance $\left(\mathrm{Ch}^{\mathrm{r}}\right)$, LacI gene, T7-Lac promoter [34] and sYFP gene (Figure S5). This fluorescent protein could reflect $540 \mathrm{~nm}$ light by the $503 \mathrm{~nm}$ exciting light. This optical signal could be observed microscopically by Confocal Microscopy and accurately detected by a Fluorescence Detector. This plasmid was transformed into E. coli BL21(DE3) (as Positive Control), E. coli BW25113 (as Negative Control) and E. coli BW25113-T7.

\section{Confocal Microscopy}

Cells harboring pACYCD-sYFP were cultured at $37^{\circ} \mathrm{C}$ for $2 \mathrm{~h}$. Then IPTG with a final concentration of $1 \mathrm{mM}$ was added to the induced group. The bacterium solution was observed under Confocal Microscopy after $4 \mathrm{~h}$ of induction.

All strains were prepared for Confocal Microscopy as stated above for fluorescence measurements and prepared as a wet mount. Confocal microscopy was performed using a Leica TCS SP2 inverted confocal microscope (Leica Microsystems, Wetzlar, Germany) equipped with a $63 \times$ water-corrected objective in multitrack mode. Collected images were analyzed with the Leica Application Suite for Advanced Fluorescence (LAS AF, version 2.35) software (Leica Microsystem).

\section{Fluorescence intensity measured by Multifunctional Microplate Detector}

Cells harboring pACYCD-sYFP were cultured in LB containing $\mathrm{Chl}$ at $37^{\circ} \mathrm{C}$ for $2 \mathrm{~h}$. Then IPTG with a final concentration of $1 \mathrm{mM}$ was added to the induced group. The fermented liquid was added to a 96 well plate after $4 \mathrm{~h}$ of induction, then accurate fluorescent data was detected by Synergy ${ }^{\text {min }}$ HTX Multifunctional Microplate Detector (BioTek Instruments, America). The excitation light was set as $503 \mathrm{~nm}$ and the receiving light was set as $540 \mathrm{~nm}$. Collected data was analyzed with the Gen $5^{\mathrm{mm}}$ V2 Data Analysis Software (BioTek Instruments, Inc.).

\section{Analytical procedures of ALA production}

Cells harboring pET28b-ALA-LA or pET28b-ALA-LAR were cultured in M9YE containing Kan at $37^{\circ} \mathrm{C}$ for $2 \mathrm{~h}$. 
Then IPTG with a final concentration of $0.1 \mathrm{mM}$ was added to the induced group. To analyze ALA production, culture $(30 \mathrm{~mL})$ after induction for $24 \mathrm{~h}$ was centrifuged $\left(12,000 \mathrm{~g}\right.$ for $2 \mathrm{~min}$ at $\left.4^{\circ} \mathrm{C}\right)$. The supernatant was used for extracellular ALA analysis. ALA concentration was analyzed using modified Ehrlich's reagent [54]. Specifically, $2 \mathrm{ml}$ of standard or sample (after diluted) was mixed with $1 \mathrm{ml} 1.0 \mathrm{M}$ sodium acetate ( $\mathrm{pH} 4.6)$ in a cuvette, and $0.5 \mathrm{ml}$ acetylacetone (2,4-pentanedi-one) was added to each cuvette. Then the mixtures were heated at $100{ }^{\circ} \mathrm{C}$ for $15 \mathrm{~min}$. After cooling for $15 \mathrm{~min}, 1 \mathrm{ml}$ of the reaction mixture and $1 \mathrm{ml}$ freshly prepared modified Ehrlich's reagent were mixed together. After $30 \mathrm{~min}$, the absorbance at $554 \mathrm{~nm}$ was measured. Standard plot for ALA measurement is shown in Figure S7.

\section{Construction of the T7 Promoter Variants Library}

Plasmid pTarget-ybhC was constructed by inverse PCR and T4-Ligation (T4 DNA Ligase, NEB, England) to make the single-base substitution mutation (Figure S5). The primers used are listed in Table S2. The plasmids were all sequenced to ensure that the single-base substitution mutation was introduced.

\section{Data Analysis}

Data for fluorescence intensity were subjected to analysis of variance (ANOVA) by GraphPad Prism (version 7.00). The quantitative fluorescent data was normalized to the cell density $\left(\mathrm{OD}_{600}\right)$. Error bars indicate standard error of the mean (SEM). P values were calculated using Tukey's multiple comparisons test $\left({ }^{*} \mathrm{P}<0.05,{ }^{* *} \mathrm{P}<0.01\right.$, ***: $\mathrm{P}<0.001)$.

\section{Abbreviations \\ E. coli: Escherichia coli; DSB: Double strand break; dsDNA: Double-stranded DNA; ssDNA: Single-stranded DNA; T7-RNAP: T7 RNA polymerase gene; Lacl gene: Lacl Operator and Int 1; HRL: Left homologous arm; HRR: Right homologous arm; Kan': Kanamycin resistance gene; sgRNA: Small-guide RNA; Chl': Chloramphenicol resistance; NHEJ: Non-Homologous End Joining; ALA: 5-Aminolevulinic Acid}

\section{Supplementary Information}

The online version contains supplementary material available at https://doi. org/10.1186/s13036-021-00270-9.

\footnotetext{
Additional file 1: Figure S1. Map of plasmids which were constructed for CRISPR. A) Map of pCas, which harbored the temperature sensitive oriR101 with repA101ts, kanamycin resistance gene, the $\lambda$-Red operon encoding Gam, Bet, and Exo proteins under the control of arabinoseinducible promoter ParaB, S. pyogenes-derived cas9 driven by endogenous promoters and sgRNA guided to ori-p15a which is under the control of lac operator. B) Map of pTarget-ybhC, which harbored Chloramphenicol resistance, ori-p15a and sgRNA guided to E. coli BW25113 ybhC gene.

Additional file 2: Figure S2. Construct of intermediate cloning vectors for preparing Donor DNA. A) Fragment A cloned from BW25113 was concatenated to pACYCD-Blank to assemble pACYCD-ybhC. B) Fragment B cloned from BL21(DE3) was concatenated to PACYCD-ybhC to assemble pACYCD-Donor. C) Map of pACYCD-Donor. D) The map of Donor DNA, which contains HRL, T7-RNAP and HRR.
}

Additional file 3: Figure S3. Confirmation of CRISPR/Cas9-mediated DSB in E. coli BW25113. The macroscopic images of colony formation after co-electroporation of Donor DNA and pTarget-ybhC.

Additional file 4: Figure S4.Detection of successful RNAP Knock in clones of BW25113-T7. A) The location of colony PCR product in BW25113-T7 genome. B) Lane M, 1 kb Plus DNA ladder (TransGen, Beijing): lanes 1 was blank; lanes 2 to 8 were samples of colony PCR; lanes 8 and 9, positive control and negative control, respectively.

Additional file 5: Figure S5.Map of PACYCD-sYFP. A) Sequence of T7Lacl promoter. B) Map of T7-Lacl promoter. C) Map of pACYCD-sYFP (p15a ori; CmR; lacl; Lac operator and T7 promoter; SYFP).

Additional file 6: Figure S6. Characterization of T7 RNAP promoter variants: Relative activity of promoter variants (From Strongest to Weakest). Promoter variants were identified by referring to the base in the non-template strand of the DNA (e.g., a -17A promoter). The height of each bar indicates the activity of each promoter relative to that of the consensus promoter (data are from Table 5). All experiments were performed in triplicates.

Additional file 7: Figure S7.Standard Plot for ALA measurement.x: the absorbance at $554 \mathrm{~nm} ; \mathrm{y}$ : ALA concentration of sample after diluted (mg/ L)

Additional file 8.

Additional file 9.

Additional file 10.

\section{Acknowledgements}

Not applicable.

\section{Authors' contributions}

Qiao and Ye designed the study, wrote and edited the manuscript. Ye conducted all experiments of this study. Ye, Chen and Yang performed experiments and analyzed experimental results. Qiao and Zeng supervised the study. All authors read and approved the final manuscript.

\section{Funding}

The work presented in this manuscript was supported by Beijing Swine Innovation Team of Modern Agriculture Industry Technological System.

\section{Availability of data and materials}

The majority of data generated or analyzed during this study are included in this published article or in the supplementary information. The data not shown in the manuscript are available upon request from the corresponding author.

\section{Declarations}

Ethics approval and consent to participate Not applicable.

\section{Consent for publication}

The content of the manuscript has been approved by all authors.

\section{Competing interests}

The authors declare that they have no competing interests.

\section{Author details}

'State Key Laboratory of Animal Nutrition, Ministry of Agriculture Feed Industry Centre, China Agricultural University, 100193 Beijing, China. ${ }^{2}$ Beijing Key Laboratory of Bio-feed Additives, 100193 Beijing, China. ${ }^{3}$ State Key Laboratory for Agro-Biotechnology, and Ministry of Agriculture and Rural Affairs, Key Laboratory for Pest Monitoring and Green Management, Department of Plant Pathology, China Agricultural University, 100193 Beijing, China. ${ }^{4}$ National Feed Engineering Technology Research Centre, 100193 Beijing, China. 
Received: 19 March 2021 Accepted: 7 June 2021

\section{Published online: 12 August 2021}

\section{References}

1. Song CW, Lee J, Lee SY. Genome engineering and gene expression control for bacterial strain development. Biotechnol J. 2015;10:56-68.

2. Baneyx F. Recombinant protein expression in Escherichia coli. Curr Opin Biotechnol. 1999;10:411-21.

3. Yamanaka K, Reynolds KA, Kersten RD, Ryan KS, Gonzalez DJ, Nizet V, Dorrestein PC, Moore BS. Direct cloning and refactoring of a silent lipopeptide biosynthetic gene cluster yields the antibiotic taromycin A. Proc Natl Acad Sci U S A. 2014;111:1957-62.

4. Shao Z, Rao G, Li C, Abil Z, Luo Y, Zhao H. Refactoring the silent spectinabilin gene cluster using a plug-and-play scaffold. ACS Synth Biol. 2013;2:662-9.

5. Temme K, Zhao D, Voigt CA. Refactoring the nitrogen fixation gene cluster from Klebsiella oxytoca. Proc Natl Acad Sci U S A. 2012;109:7085-90.

6. Brown S, Clastre M, Courdavault V, O'Connor SE. De novo production of the plant-derived alkaloid strictosidine in yeast. Proc Natl Acad Sci U S A. 2015; 112:3205-10.

7. Soliman S, Tang Y. Natural and engineered production of taxadiene with taxadiene synthase. Biotechnol Bioeng. 2015;112:229-35.

8. Park JH, Lee KH, Kim TY, Lee SY. Metabolic engineering of Escherichia coli for the production of L-valine based on transcriptome analysis and in silico gene knockout simulation. Proc Natl Acad Sci U S A. 2007;104:7797-802.

9. Lee KH, Park JH, Kim TY, Kim HU, Lee SY. Systems metabolic engineering of Escherichia coli for L-threonine production. Mol Syst Biol. 2007;3:149.

10. Lee TS, Krupa RA, Zhang F, Hajimorad M, Holtz WJ, Prasad N, Lee SK, Keasling JD. BglBrick vectors and datasheets: A synthetic biology platform for gene expression. J Biol Eng. 2011;5:12.

11. Dahl RH, Zhang F, Alonso-Gutierrez J, Baidoo E, Batth TS, Redding-Johanson AM, Petzold CJ, Mukhopadhyay A, Lee TS, Adams PD, Keasling JD. Engineering dynamic pathway regulation using stress-response promoters. Nat Biotechnol. 2013;31:1039-46.

12. Zhang F, Carothers JM, Keasling JD, Joint Bioenergy I. Design of a dynamic sensor-regulator system for production of chemicals and fuels derived from fatty acids. Nat Biotechnol. 2012;30:354-9.

13. Cameron DE, Collins JJ. Tunable protein degradation in bacteria. Nat Biotechnol. 2014;32:1276-81.

14. Wang HH, Isaacs FJ, Carr PA, Sun ZZ, Xu G, Forest CR, Church GM. Programming cells by multiplex genome engineering and accelerated evolution. Nature. 2009;460:894-8.

15. Hsu PD, Lander ES, Zhang F. Development and applications of CRISPR-Cas9 for genome engineering. Cell. 2014;157:1262-78.

16. Lee SY. High cell-density culture of Escherichia coli. Trends Biotechnol. 1996; 14:98-105.

17. Yee L, Blanch HW. Recombinant protein expression in high cell density fedbatch cultures of Escherichia coli. Biotechnology. 1992;10:1550-6.

18. Singleton P. Bacteria in biology, biotechnology and medicine. 1999;5 ed, vol 157. Wiley.

19. Himmel ME, Karplus PA, Sakon J, Adney WS, Baker JO, Thomas SR. Polysaccharide hydrolase folds diversity of structure and convergence of function. Appl Biochem Biotechnol. 1997;63-65:315-25.

20. Studier FW, Moffatt BA. Use of bacteriophage T7 RNA polymerase to direct selective high-level expression of cloned genes. J Mol Biol. 1986;189:113-30.

21. Studier FW, Rosenberg AH, Dunn JJ, Dubendorff JW. Use of T7 RNA polymerase to direct expression of cloned genes. Methods Enzymol. 1990; 185:60-89.

22. Jinek M, Chylinski K, Fonfara I, Hauer M, Doudna JA, Charpentier E. A programmable dual-RNA-guided DNA endonuclease in adaptive bacterial immunity. Science. 2012;337:816-21.

23. Horvath P, Barrangou R. CRISPR/Cas, the immune system of bacteria and archaea. Science. 2010;327:167-70.

24. Chung ME, Yeh IH, Sung LY, Wu MY, Chao YP, Ng IS, Hu YC. Enhanced integration of large DNA into E. coli chromosome by CRISPR/Cas9. Biotechnol bioeng. 2017;114:172-83.

25. Yu D, Ellis HM, Lee EC, Jenkins NA, Copeland NG, Court DL. An efficient recombination system for chromosome engineering in Escherichia coli. Proc Natl Acad Sci U S A. 2000;97:5978-83.

26. Court DL, Sawitzke JA, Thomason LC. Genetic engineering using homologous recombination. Annu Rev Genet. 2002;36:361-88.
27. Wang H, La Russa M, Qi LS. CRISPR Cas9 in genome editing and beyond. Annu Rev Biochem. 2016;85:227-64.

28. Baba T, Ara T, Hasegawa M, Takai Y, Okumura Y, Baba M, Datsenko KA, Tomita M, Wanner BL, Mori H. Construction of Escherichia coli K-12 in-frame, single-gene knockout mutants: the Keio collection. Mol Syst Biol 2006;2:2006.0001-2006.0008

29. Yamamoto N, Nakahigashi K, Nakamichi T, Yoshino M, Takai Y, Touda Y, Furubayashi A, Kinjyo S, Dose H, Hasegawa M, Datsenko KA, Nakayashiki T, Tomita M, Wanner BL, Mori H. Update on the Keio collection of Escherichia coli single-gene deletion mutants. Mol Syst Biol. 2009;5:335.

30. Nichols RJ, Sen S, Choo YJ, Beltrao P, Zietek M, Chaba R, Lee S, Kazmierczak KM, Lee KJ, Wong A, Shales M, Lovett S, Winkler ME, Krogan NJ, Typas A, Gross CA. Phenotypic landscape of a bacterial cell. Cell. 2011;144:143-56.

31. Mutalik VK, Guimaraes JC, Cambray G, Mai QA, Christoffersen MJ, Martin L, Yu A, Lam C, Rodriguez C, Bennett G, Keasling JD, Endy D, Arkin AP. Quantitative estimation of activity and quality for collections of functional genetic elements. Nat Methods. 2013;10:347-53

32. Mutalik VK, Guimaraes JC, Cambray G, Lam C, Christoffersen MJ, Mai QA, Tran AB, Paull M, Keasling JD, Arkin AP, Endy D. Precise and reliable gene expression via standard transcription and translation initiation elements. Nat Methods. 2013;10:354-60.

33. Cambray G, Guimaraes JC, Mutalik VK, Lam C, Mai QA, Thimmaiah T, Carothers JM, Arkin AP, Endy D. Measurement and modeling of intrinsic transcription terminators. Nucleic Acids Res. 2013;41:5139-48.

34. Dubendorff JW, Studier FW. Controlling basal expression in an inducible T7 expression system by blocking the target $\mathrm{T} 7$ promoter with lac repressor. J Mol Biol. 1991;219:45-59.

35. Pyne ME, Moo-Young M, Chung DA, Chou CP. Coupling the CRISPR/Cas9 system with lambda red recombineering enables simplified chromosomal gene replacement in Escherichia coli. Appl Environ Microbiol. 2015;81:5103-14.

36. Wilson TE, Topper LM, Palmbos PL. Non-homologous end-joining: bacteria join the chromosome breakdance. Trends Biochem Sci. 2003;28:62-6.

37. Michel B. After 30 years of study, the bacterial SOS response still surprises us. PLoS Biol. 2005:3:e255.

38. Cong L, Ran FA, Cox D, Lin S, Barretto R, Habib N, Hsu PD, Wu X, Jiang W, Marraffini LA, Zhang F. Multiplex genome engineering using CRISPR/Cas systems. Science. 2013;339:819-23.

39. Kang Z, Wang Y, Gu P, Wang Q, Qi Q. Engineering Escherichia coli for efficient production of 5-aminolevulinic acid from glucose. Metab Eng. 2011;13:492-8.

40. Bhowmick R, Girotti AW. Cytoprotective induction of nitric oxide synthase in a cellular model of 5-aminolevulinic acid-based photodynamic therapy. Free Radic Biol Med. 2010;48:1296-301.

41. Mikolajewska P, Donnelly RF, Garland MJ, Morrow DI, Singh TR, lani V, Moan J, Juzeniene A. Microneedle pre-treatment of human skin improves 5aminolevulininc acid (ALA) and 5-aminolevulinic acid methylester (MAL)induced PpIX production for topical photodynamic therapy without increase in pain or erythema. Pharm Res. 2010;27:2213-20.

42. Sakamoto FH, Torezan L, Anderson RR. Photodynamic therapy for acne vulgaris: a critical review from basics to clinical practice: part II. Understanding parameters for acne treatment with photodynamic therapy. J Am Acad Dermatol. 2010;63:195-211.

43. Sasaki $K$, Watanabe M, Tanaka T, Tanaka T. Biosynthesis, biotechnological production and applications of 5-aminolevulinic acid. Appl Microbiol Biot. 2002:58:23-9.

44. Edwards S, Jackson D, Reynoldson J, Shanley B. Neuropharmacology of $\delta$ aminolaevulinic acid. II. Effect of chronic administration in mice. Neurosci Lett. 1984;50:169-73.

45. Yang $X$, Li W, Palasuberniam P, Myers KA, Wang C, Chen B. Effects of silencing heme biosynthesis enzymes on 5-aminolevulinic acid-mediated protoporphyrin IX fluorescence and photodynamic therapy. Photochem Photobiol. 2015;91:923-30.

46. Kannangara CG, Söll D, Gough S, Krupp G, Schön A, Berry-Lowe S. The RNA required in the first step of chlorophyll biosynthesis is a chloroplast glutamate tRNA. Nature. 1986;322:281-4.

47. Lopez PJ, Guillerez J, Sousa R, Dreyfus M. On the mechanism of inhibition of phage T7 RNA polymerase by lac repressor. J Mol Biol. 1998;276:861-75.

48. Maser A, Peebo K, Nahku R. Avoiding amino acid depletion in a complex medium results in improved Escherichia coli BW25113 growth. Microbiology. 2019:165:37-46.

49. Maser A, Peebo K, Vilu R, Nahku R. Amino acids are key substrates to Escherichia coli BW25113 for achieving high specific growth rate. Res Microbiol. 2020;171:185-93. 
50. Khazen S, Molenaar C, Wiesmeijer K, Verwoerd NP, Eils R, Tanke HJ, Dirks RW. Visualizing telomere dynamics in living mammalian cells using PNA probes. EMBO J. 2003;22:6631-41.

51. Peng R, Lin G, Li J. Potential pitfalls of CRISPR/Cas9-mediated genome editing. FEBS J. 2016;283:1218-31.

52. Hsu PD, Scott DA, Weinstein JA, Ran FA, Konermann S, Agarwala V, Li Y, Fine EJ, Wu X, Shalem O, Cradick TJ, Marraffini LA, Bao G, Zhang F. DNA targeting specificity of RNA-guided Cas9 nucleases. Nat biotechnol. 2013;31: 827-32.

53. Phelan RM, Sachs D, Petkiewicz SJ, Barajas JF, Blake-Hedges JM, Thompson MG, Reider Apel A, Rasor BJ, Katz L, Keasling JD. Development of next generation synthetic biology tools for use in Streptomyces venezuelae. ACS Synth Biol. 2017:6:159-66.

54. Burnham BF. 8-Aminolevulinic acid synthase (Rhodopseudomonas sphaeroides). Methods Enzymol. 1970;17A:195-204.

\section{Publisher's Note}

Springer Nature remains neutral with regard to jurisdictional claims in published maps and institutional affiliations.

Ready to submit your research? Choose BMC and benefit from:

- fast, convenient online submission

- thorough peer review by experienced researchers in your field

- rapid publication on acceptance

- support for research data, including large and complex data types

- gold Open Access which fosters wider collaboration and increased citations

- maximum visibility for your research: over $100 \mathrm{M}$ website views per year

At BMC, research is always in progress.

Learn more biomedcentral.com/submissions 